\title{
PEMBELAJARAN ILMU PENGETAHUAN SOSIAL DAN PENDIDIKAN KARAKTER DI SEKOLAH DASAR
}

\author{
Soebijantoro *
}

\begin{abstract}
Character education relates to all of ability of any individual to interact with the environment, which copes with moral, attitude and behavior. One's character is supposed to be good if he / she has moral knowledge, sense and action. Substantially, moral education is carried out affectively which deals with mentality, courage and hope, image and belief. Best belief of something is the result of learning process, coping with rational internalization about truths and wellbeing. Social Science is hoped to serve the moral education content, since it facilitates students with ability to adapt to the environment, to build knowledge, and to nurture the culture. All of those performances can be developed by the aplication of varied approaches of Social science.
\end{abstract}

Key words: Social Scence Learning, Character Education

\begin{abstract}
Abstrak
Pendidikan karakter berkaitan dengan keseluruhan kemampuan seseorang dalam berinteraksi dengan lingkungannya, sebab hal itu berkaitan dengan unsur moral, sikap sampai dengan perilaku. Sebuah karakter dikatakan baik apabila seseorang memiliki kemampuan atas pengetahuan sebuah moral, perasaan moral dan tindakan moral. Secara substantif pendidikan karakter berkenaan dengan pendidikan afektif yaitu berkenaan dengan dunia kejiwaan, cita-cita dan rasa, citra serta keyakinan manusia. Keyakinan akan sesuatu yang paling baik merupakan hasil belajar. Sebagai hasil dari proses internalisasi secara nalar dari peserta didik terhadap nilai-nilai kebenaran dan kebaikan. IPS merupakan rumpun yang diharapkan dapat memberikan muatan besar pendidikan karakter sebab IPS mampu memfasilitasi peserta didik untuk membangun pengetahuan, beradaptasi dengan lingkungan, membudayakan dirinya dengan lingkungan yang kesemuanya dapat dikembangkan melalui pembelajaran dengan pendekatan berbagai disiplin ilmu-ilmu sosial.
\end{abstract}

Kata Kunci: Pembelajaran IPS, Pendidikan Karakter

* Soebijantoro adalah Dosen Prodi Pendidikan Sejarah IKIP PGRI Madiun 


\section{A. Pendahuluan}

Harus diakui secara jujur bahwa bangsa Indonesia sedang mengalami krisis multidimensi yang sudah merambah berbagai segi kehidupan yang bergerak multilini baik vertikal maupun horizontal. Sudah lebih dari satu dekade krisis belum pulih dalam arti kehidupan masyarakat bukannya semakin baik akan tetapi bergerak dalam kondisi status quo (Suhartono, 2011: 1). Terlepas apakah penyebab utama adalah karena faktor krisis ekonomi global akan tetapi yang jelas dampaknya sangat kompleks dan recovery yang dilakukan sangatlah lamban. Karena ada berbagai kelemahan yang bersifat internal yang dialami bangsa Indonesia sebagai akibat dari kondisi sebelumnya yang tidak sehat.

Sampai saat ini pula keprihatinan demi keprihatinan telah diungkapkan oleh berbagai elemen masyarakat yang masih berharap bahwa krisis multidimensi ini segera berakhir. Kartodirjo (1999: 290) mencatat sejumlah persoalan besar sedang dihadapi oleh bangsa Indonesia. Persoalan tersebut berkisar pada masalah prasangka religius, sentimen antar etnik, eksklusivisme, sektarianisme, dan komunalisme yang bermuara pada transformasi struktural masyarakat Indonesia dalam segala dimensinya. Masalah-masalah tersebut muncul terkait dengan kemajemukan masyarakat Indonesia. Sehingga masyarakat Indonesia dihadapkan pada kebutuhan yang mendesak untuk merekonstruksi kembali kebudayaan nasional yang dapat menjadi kekuatan penyatu mengikat seluruh keragaman. Apresiasi akan hal itu disebabkan karena fakta historis menunjukkan bahwa bangsa Indonesia telah menunjukkan kemampuan beradaptasi dan menerima budaya-budaya besar sehingga dapat memperkecil perbedaan-perbedaan tersebut.

Berangkat dari fakta historis tersebut akan melahirkan sebuah pertanyaan pada diri kita mengapa krisis tersebut harus terjadi sekarang? Menurut Suhartono (2011: 2) dijelaskan bahwa salah satu entry point untuk mengurai carut marut problem bangsa ini yang mengarah pada perilaku negatif yang menurunkan pamor pemerintah karena bangsa ini telah kehilangan banyak karakter positif. Karakter tidak lain adalah pegangan dalam berperilaku (positif) dalam masyarakat yang karena berbagai hal telah tereduksi. Sehubungan dengan lemahnya karakter itu diperlukan revitalisasi atau penguatan kembali seperti yang pernah melekat pada diri Presiden Soekarno yang selalu menekankan perlunya pembangun karakter bangsa (nation and character building ). Sehingga apabila hal tersebut merupakan masalah yang sangat urgen maka hal tersebut dapat dipergunakan sebagai sebuah refleksi kritis atas kehidupan bermasyarakat, berbangsa dan bernegara baik pada masa kini maupun pada masa yang akan datang.

Karakter bangsa merupakan spirit spiritual yang diperlukan untuk mengembalikan esensi negara kesatuan yang dapat meyakinkan bahkan menyatakan bahwa etnisitas ada dalam kesatuan Republik Indonesia. Untuk itu diperlukan pendidikan karakter bangsa guna mengisi atau member bekal generasi muda dalam melanjutkan estafet kepemimpinan bangsa. Hal ini tidaklah berlebihan sebab sangatlah aneh apabila sebuah bangsa bisa hidup dengan karakter lemah ibarat wayang kulit tanpa gapit (cempurit). Gapit merupakan kekuatan spiritual yang tidak lain adalah karakter yang membangun kekuatan.

Krisis multidimensi harus segera diatasi dan merupakan kebutuhan yang sangat mendesak, maka semua elemen masyarakat tanpa terkecuali termasuk 
pelaku pendidikan untuk memahami bahwa pendidikan karakter harus diberikan sejak dini. Pendidikan yang berorientasi pada proses meyakini bahwa meski memerlukan waktu yang panjang (long term education) dipastikan hasilnya sangat menjanjikan. Pendidikan moral dan perilaku tentunya bukan hanya pendidikan di kelas, tetapi pendidikan di keluarga menjadi sangat penting mengingat di sini akan diawali sebuah pendidikan karakter. Selanjutnya sekolah termasuk akan sekolah dasar adalah sebagai tempat pendidikan karakter yang kedua di mana masyarakat akan ikut mengontrol.

\section{B. Pembahasan}

\section{Pembelajaran Pendidikan Karakter}

Secara substantif pendidikan karakter berkaitan dengan pendidikan afektif. Aspek afektif menurut Graham merupakan aspek yang berkaitan dengan apa yang terdapat dalam diri peserta didik (the internal side) sehingga keberadaannya selalu tersembunyi sebab ini berkenaan dengan dunia kejiwaan, cita-cita, dan rasa (Masrukhi, 2011: 3). Aspek yang bersifat hidden dan berada di dalam diri peserta didik sangat sulit untuk diketahui dan diukur, apalagi untuk dibina dan diarahkan melalui proses belajar mengajar di kelas. Oleh karena itulah banyak tokoh pendidikan yang merasa pesimis bahwa dunia pendidikan / pengajaran akan dapat mampu menyentuh afektif ini. Setidaknya ada tiga paham yang memiliki argumentasi yang menaifkan untuk melakukan pengajaran pada aspek afektif.

Pertama adalah paham kebebasan situasional. Kedua adalah paham kebebasan yang berargumentasi tidak perlu dan tidak boleh diajarkan aspek afektif ini karena bertentangan dengan hakikat kebebasan dasar manusia untuk menentukan pilihannya secara bebas dan mandiri. Ketiga adalah paham absolutisme yang beranggapan bahwa tidak perlu dimasukkannya aspek afektif dalam proses belajar mengajar karena segala nilai dan norma yang ada sudah dianggap baik dan dilaksanakan secara umum, wajib dianut dan dilaksanakan tanpa peduli apakah setuju atau tidak. Ketiga paham tersebut beranggapan bahwa aspek afektif tidak dapat disentuh oleh dunia pendidikan dan pengajaran.

Namun seiring dengan perkembangan dunia psikologi pendidikan dalam melakukan penemuan-penemuan baru mengenai dunia kejiwaan manusia, maka muncullah rasa optimis akan peran aspek afektif dalam dunia pendidikan dan pengajaran. Tokoh-tokoh seperti Piaget, Kohlberg, dan Metcalf, mereka berpendapat bahwa keyakinan akan sesuatu yang paling baik hendaklah merupakan hasil belajar (learned behavior) sebagai hasil dari proses internalisasi secara nalar dari para siswa terhadap nilai-nilai kebenaran dan kebaikan. Learned behavior dari pendidikan karakter pun yang dapat diketahui dan ditelaah hanyalah indikator-indikatornya saja yaitu berupa tingkah laku yang nampak dari luar. Perilaku yang dimaksud menurut Fraenkel meliputi cita-cita dan tujuan yang dianut atau diutarakan seseorang, sikap yang ditampilkan atau ditampakkan, perasaan yang diutamakan maupun perbuatan yang dilakukan bahkan rasa kekhawatiran sekalipun (Masrukhi, 2011: 4). Dari penjelasan tersebut sangat jelas bahwa perilaku positif individu akan dapat dibentuk melalui proses belajar mengajar yang berkesinambungan. 
Salah satu rumpun mata pelajaran yang dilaksanakan dalam proses belajar mengajar di sekolah termasuk di sekolah dasar adalah Ilmu Pengetahuan Sosial (IPS). Mata pelajaran ini diharapkan dapat memberikan muatan besar pada pendidikan karakter. Namun dari hasil penelitian beberapa ahli pendidikan di Kota Semarang tahun 2008 menunjukkan hasil bahwa proses belajar mengajar IPS cenderung menitik beratkan pada penguasaan hafalan, masih terpusatnya pembelajaran pada guru, terjadinya miskonsepsi, pembelajaran yang tidak menyenangkan, ketidakmutakhiran sumber belajar kemudian kontradiktif materi dengan kenyataan hingga rasa pesimis akan peran dan kedudukan ilmu-ilmu sosial pembangunan masyarakat.

Pendidikan karakter berkenaan dengan keseluruhan performance seseorang dalam berinteraksi dengan lingkungan, sehingga di dalam karakter ini terkandung unsur moral, sikap sampai perilaku. Sulit rasanya mendeteksi seseorang memiliki karakter yang baik atau jelek, manakala karena untuk menentukan apakah seseorang memiliki akhlak atau budi belum menyaksikan dan merasakan perbuatan atau perilaku tertentu dari orang tersebut. Menurut Cronbach karakter adalah sebuah kualitas moral yang akan selalu tereintegrasi dengan kematangan intelektual dan emosional. Melalui media pendidikan karakter seseorang akan nampak pada kemampuan memahami moral, merasakan adanya moral dan tindakan nyata dari moral yang kesemuanya akan menciptakan sikap yaitu: (1) tanggung jawab moral; (2) memahami nilai-nilai moral; (3) sanggup mengambil keputusan; (4) pengetahuan akan diri sendiri; (5) empati; (6) menghargai sebuah kebaikan; (7) kemampuan mengontrol diri sendiri; (8) kemanusiaan; (9) kompetensi; (10) tindakan; dan (11) kebiasaan.

\section{Pembelajaran IPS di Sekolah Dasar}

Pendidikan karakter tiba-tiba muncul menjadi sebuah tren yang sangat kuat dalam dunia pendidikan di Indonesia. Hal ini terkait dengan realitas bahwa kondisi sosial kemasyarakatan bangsa pasca reformasi yang memperlihatkan betapa semakin jauhnya sikap dan perilaku warga dari tatanan nilai dan moral. Apabila dikaitkan dengan nilai filosofis bangsa (Pancasila) maka potret tersebut di atas berada pada titik balik. Sehingga apabila terdapat keinginan untuk mengurai benang kusut tersebut, maka paparan yang dapat dipergunakan untuk memulainya adalah dengan melihat realitas kehidupan sosial masyarakat itu sendiri. Seperti yang sudah disampaikan di atas bahwa banyak harapan yang ditumpukan kepada peran pendidikan IPS untuk memberikan kontribusi pendidikan karakter di sekolah. Namun tidaklah mudah untuk mengatakan bahwa IPS merupakan satusatunya harapan agar pendidikan karakter dapat dibangun melalui pendidikan formal. Dalam konteks pendidikan karakter semua mata pelajaran, semua elemen masyarakat ikut pula bertanggung jawab terhadap terwujudnya pendidikan karakter yang diharapkan. Terdapat beberapa alasan perlunya kita mengkaji keberadaan mata pelajaran IPS di sekolah dasar saat ini bahwa masih terdapat anggapan bahwa mata pelajaran IPS adalah mata pelajaran yang tidak penting, membosankan, mudah dipelajari serta tidak memiliki kontribusi dalam pembangunan individu bangsa bahkan negara (Abraham, 2010). 
Tidaklah berlebihan apabila anggapan-anggapan tersebut kita kaitkan dengan fakta di lapangan yang menunjukkan bahwa apresiasi masyarakat terhadap keberadaan mata pelajaran yang diberikan di sekolah akan berbeda bila dikaitkan dengan standar kelulusan siswa yang ditunjukkan melalui ujian akhir nasional (UAN). Potret paradigma pembelajaran dan pengajaran IPS saat ini adalah masih terdapat anggapan bahwa belajar IPS adalah mudah/tidak penting bahkan tidak terdapat kontribusi IPS bagi bangsa dan negara. IPS baru dianggap penting apabila mata pelajaran IPS menjadi bagian dari indikator kelulusan (UTS / UAS / UAN).

Paradigma pembelajaran IPS tidak hanya berkutat pada ranah kognitif melainkan afektif dan psikomotor, hal ini tidak lepas dari karakteristik pembelajaran IPS seperti yang dijelaskan oleh Nasution (1989:60-63) bahwa pendidikan IPS ialah suatu program pendidikan yang mengkaji manusia dalam lingkungan alam fisik maupun lingkungan sosialnya dimana materi kajiannya diperoleh dari berbagai ilmu sosial seperti geografi, penyederhanaan dari ilmuilmu sosial, termasuk di dalamnya sosiologi, sejarah, ekonomi, antropologi, politik, psikologi. Berdasarkan pengertian tersebut maka dapat dikemukakan bahwa Pendidikan IPS merupakan disiplin ilmu sintetis yang bahan-bahannya bersumber dari ilmu-ilmu sosial dan humaniora yang diorganisasikan dan disajikan secara ilmiah dan psikologis untuk tujuan pendidikan. Dengan demikian seorang guru IPS harus mempunyai kompetensi didalam memahami dimensi mata pelajaran IPS yang sesungguhnya memuat nilai-nilai yang menjadi basis pendidikan karakter. Karakteristik tersebut secara umum nampak dalam Tabel 1.

Tabel 1 Dimensi IPS dalam Kehidupan Manusia

\begin{tabular}{llll}
\hline $\begin{array}{c}\text { Dimensi dalam } \\
\text { kehidupan manusia }\end{array}$ & \multicolumn{1}{c}{ Ruang } & \multicolumn{1}{c}{ Waktu } & \multicolumn{1}{c}{ Nilai/Norma } \\
\hline $\begin{array}{l}\text { Area dan substansi } \\
\text { pembelajaran }\end{array}$ & $\begin{array}{l}\text { Alam sebagai } \\
\text { tempat dan } \\
\text { penyedia potensi } \\
\text { sumber daya }\end{array}$ & $\begin{array}{l}\text { Alam dan } \\
\text { kehidupan yang } \\
\text { selalu berproses, } \\
\text { masa lalu, saat ini, } \\
\text { dan yang akan } \\
\text { datang }\end{array}$ & $\begin{array}{l}\text { Kaidah atau aturan } \\
\text { yang menjadi perekat } \\
\text { dan penjamin } \\
\text { keharmonisan } \\
\text { kehidupan manusia } \\
\text { dan alam }\end{array}$ \\
\hline $\begin{array}{l}\text { Contoh Kompetensi } \\
\begin{array}{l}\text { Dasar yang } \\
\text { dikembangkan }\end{array}\end{array}$ & $\begin{array}{l}\text { Adaptasi spasial } \\
\text { dan eksploratif }\end{array}$ & $\begin{array}{l}\text { Berpikir } \\
\text { kronologis, } \\
\text { prospektif, } \\
\text { antisipatif }\end{array}$ & $\begin{array}{l}\text { Konsisten dengan } \\
\text { aturan yang } \\
\text { disepakati dan kaidah } \\
\text { ilmiah masing- } \\
\text { masing disiplin ilmu }\end{array}$ \\
\hline $\begin{array}{l}\text { Alternatif penyajian } \\
\text { dalam mata pelajaran }\end{array}$ & Geografi & Sejarah & $\begin{array}{l}\text { Ekonomi, Sosiologi / } \\
\text { Antropologi }\end{array}$ \\
\hline
\end{tabular}

Sumber: Sardiman (2004: 25)

Berdasarkan Tabel 1 nampak secara ideal bahwa IPS mengkonsepsikan karakteristik pendidikan agar: (a) secara kognitif peserta didik dilatih dan dibekali dengan pengetahuan konseptual yang layak, kemampuan berpikir dan memecahkan masalah yang cukup; (b) peserta didik dibekali kemampuan penalaran dan belajar yang luas; (c) secara moral-afektual dibina dengan bekal 
tatanan nilai, keyakinan dan keadilannya maupun pengalaman dan kemampuan afektual peserta didik; dan (d) secara sosial peserta didik dibina ketegaran akan harga diri dan konsep diri serta kemampuan melakukan hubungan interpersonal (Daljuni 1992:35).

Dengan demikian implementasi kurikulum IPS pada pendidikan dasar secara ideal harus mampu membentuk peserta didik yang baik dan mampu berpikir secara cerdas, mampu menyeleksi dan mengaplikasikan nilai-nilai yang ada dalam agama, kebudayaan, bangsa dan negara. Sehingga diharapkan tujuan pembelajaran IPS yang dikelompokkan dalam empat kategori dapat terwujud. Empat kategori tersebut adalah: (1) knowledge, yang merupakan tujuan utama Pendidikan IPS, yaitu membantu peserta didik belajar tentang diri mereka sendiri dan lingkungannya. Hal-hal yang dipelajari dalam konteks ini adalah geografi, sejarah, politik, ekonomi, antropologi dan sosiopsikologi; (2) keterampilan, yang berhubungan dengan tujuan Pendidikan IPS, dalam hal ini mencakup keterampilan berpikir (thinking skills); (3) attitudes (sikap), dikelompokkan menjadi dua, yaitu kelompok sikap yang diperlukan untuk tingkah laku berpikir (intelectual behaviour) dan tingkah laku sosial (sosial behaviour); dan (4) value, dalam hubungan ini adalah nilai yang terkandung dalam masyarakat yang didapatkan dari lingkungan masyarakat sekitar maupun lembaga pemerintahan (falsafah bangsa). Termasuk didalamnya adalah nilai-nilai kepercayaan, nilai ekonomi, pergaulan antarmanusia, ketaatan pada pemerintah, dan hukum (Jarolimek, 1982:56).

Oleh karena pendidikan IPS menekankan kepada kemampuan peserta didik dalam memahami bagaimana sebuah nilai muncul dan dilaksanakan dalam kehidupan bermasyarakat, maka seorang guru khususnya di sekolah dasar dituntut memiliki kemampuan untuk menguasai hakekat proses belajar-mengajar baik di kelas rendah maupun tinggi. Hal ini tidak lepas identifikasi perkembangan berpikir anak yang dapat diklasifikasikan ke dalam tahapan-tahapan seperti pada Tabel 2.

Tabel 2 Tahapan Perkembangan

\begin{tabular}{cll}
\hline No & \multicolumn{1}{c}{ Usia } & \multicolumn{1}{c}{ Nama Tahapan } \\
\hline 1 & $0-2$ tahun & Sensorimotor \\
\hline 2 & $2-7$ tahun & Praoperasional \\
\hline 3 & $7-11$ tahun & Operasi konkret \\
\hline 4 & 11 tahun lebih & Operasi formal \\
\hline
\end{tabular}

Sumber: Gresley dalam Winataputra (2001:114)

Berdasarkan Tabel 2 terlihat bahwa bila dikaitkan dengan usia anak di Sekolah Dasar maka Kelas I, II, dan III termasuk ke dalam tahapan operasi konket berarti yang menjadi dasar (entry behavior) adalah tahapan praoperasional dalam artian bahwa proses belajar yang bermakna apabila peserta didik memperoleh pengalaman baru yang dipadu dengan pengalaman lama. Dengan demikian pada tahapan ini seoang siswa mulai memperlihatkan kemampuan berpikir secara operasional untuk mengklasifikasikan benda-benda, mempergunakan kemampuan interelasi terhadap aturan-aturan sebab akibat dan memandang dunia secara 
obektif begerak dari satu aspek ke aspek yang lain secara reflektif dan memandang unsur-unsur secara serentak. Sehingga secara keseluruhan terdapat kecenderungan bahwa berangkat dari sesuatu yang konkret maka seorang guru dalam proses belajar mengajar dituntut untuk menemukan pengalaman baru yang berangkat dari lingkungan terdekat ke lingkungan yang lebih luas dengan memperhatikan kerucut pengalaman dalam peragaan konkret ke abstrak sehingga nampak jelas bagaimana mereka akan berperilaku.

Disamping memahami bagaimana hakekat proses pembelajaran di kelas rendah, maka seorang guru IPS dituntut untuk memahami pula hal serupa yang terjadi pada siswa kelas tinggi. Kelas tinggi sering diidentifikasi dengan kelas IV, $\mathrm{V}$, dan VI artinya bahwa pada umumnya terdiri dari peserta didik yang berusia 9 sampai dengan 14 tahun. Dengan demikian berarti rentang usia ini adalah berada pada tahap operasi konkrit dan operasi formal. Tahap operasi formal merupakan tahap perkembangan kognitif paling tinggi dan mrupakan tahap lebih matang dan lebih kompleks dari ada tahap sebelumnya. Terdapat kecenderungan berkembang berpikir tentang masa depan dan peran dewasa, mampu untuk membentuk hipotesis dan bekerja dengan proporsi rasio yang dimilikinya serta mampu untuk membangun dan memahami penjelasan yang rumit mencakup rangkaian deduktif dari logika.

Dengan kemampuan kognitifnya dan empirisnya maka seorang guru IPS didalam upaya untuk menanamkan nilai-nilai pendidikan karakter dapat dilakukan melalui kemampuan afeksi peserta didik yang diawali dari rasa kepercayaan yang paling mendasar, rasa otonomi / otoritas, kemampuan berinisiatif, kemampuan untuk berproduksi / menciptakan sesuatu, aktualisasi identitas, dan keakraban. Kualitas afektif semacam ini tentu tidak lepas dari interaksi perkembangan biologis, psikologis maupun sosial. Dengan demikian konsep perkembangan afektif diharapkan dapat meningkatkan kualitas produk dan identitas peserta didik dan melalui pembelajaran IPS nilai-nilai dari pendidikan karakter peserta didik akan mendapat pula kesempatan yang luas dan terarah untuk apat berbuat secara produktif dan mandiri.

Dengan memahami hakekat proses belajar mengajar di kelas rendah dan tinggi, seorang guru IPS harus mampu membentukan alternatif model pembelajaran. Sebab proses pembelajaran merupakan proses komunikasi yang berkarakteristik interaksi edukatifyang komunikasi timbal balik antara guru dengan peserta didik dalam mencapai suatu tujuan pembelajaran. Oleh karena itu sumber belajar yang disusun atau dirancang akan dapat merangsang timblnya dialog internal dalam diri peserta didik atau terdapat komunikasi bermakna antara peserta didik dengan sumber belajar. Dengan tercapainya dialog internal pada diri peserta didik menjadikan mereka beruasaha untuk menangkap pesan dari media tersebut, sehingga telah terjadi proses pembelajaran. Media berhasil membawakan pesan sebagai sumber belajar, apabila kemudian terjadi perubahan pola pikir, tingkah laku atau sikap belajarpada diri peserta didik (Miarso, 2003: 10).

Perencanaan-perencanaan pesan pembangunan karakter dalam proses pembelajaran sangat diperlukan. Perencanaan yang dimaksud adalah disesuaikan dengan tingkat psikologi siswa sehingga akan menghasilkan pembelajaran yang kondusif yang pada gilirannya akan tertanam konsep-konsep pembangunan 
karakter dalam tingkatan yang sangat sederhana dan konkrit. Penanaman karakter pada peserta didik merupakan proses penyesuaian kepribadian yang perlu memperhatikan bermacam-macam prinsip dasar pertumbuhan. Menurut Satmoko (2007: 4) hal ini disebabkan karena mekanisme penyesuaian tersebut pada dasaranya merupakan sebagian dari usaha kependidikan yang dilakukan baik keluarga, sekolah, maupun masyarakat dan itu berlangsung seterusnya. Untuk itulah seorang guru dituntut untuk dapat merencanakan pembelajaran yang praktis, aplikabel dan memperhatikan perkembangan dan pertumbuhan peserta didik dalam upaya pembelajaran nilai yang membawa muatan pembangunan karakter.

Terdapat banyak model pembelajaran yang memungkinkan penuangan nilai pembangunan karakter di Sekolah Dasar. Sebagai salah satu mata pelajaran maka kata kunci yang harus dipahami oleh guru adalah bahwa IPS mengharuskan siswa untuk dapat memahami diri dan lingkungannya, kemudian pelajaran itu diharapkan pula dapat menciptakan kehidupan yang lebih menyenangkan dan betul-betul memberikan kegunaan dalam hidupnya (Wahab, 2007:30). Salah satu diantaranya adalah model role playing atau bermain peran. Model ini sering dipergunakan oleh guru dalam upaya menerapkan tujuan terapi antar individu melalui bentuk psikodrama untuk analisis transaksional. Bermain peran mengandung pribadi dan dimensi sosial. Dari sisi dimensi pribadi metode ini bermanfaat bagi dirinya, sedangkan dilihat dari dimensi sosial metode ini akan mengajak semua peserta didik untuk bersama-sama memikirkan pemecahan permasalahan yang sedang dihadapi.

Pada dasarnya metode ini berupaya untuk melatih siswa bahwa peserta didik adalah mahkluk yang berperan artinya selalu akan berhadapan dengan peran-eparan yang harus dihadapi dalam kehidupan riil atau sosial. Sehingga peserta didik harus belajar untuk menangkap pesan, perasaan, tindakan maupun pola dalam berinteraksi antar individu maupun dengan lingkungan sosialnya. Dalam model bermain peran ini, peranan guru sangat menentukan, fungsi guru antara lain memotivasi peserta didik, menghargai peserta didik dan berupaya mempertemukan perbedaan pendapat dikalangan peserta didik dan mendidik untuk berpikir dan berpandangan luas.

\section{Simpulan}

Dari penjelasan tersebut diatas maka dapat disimpulkan bahwa pendidikan karakter saat ini sangat dibutuhkan sebab hal ini berkenaan dengan fakta sosial bahwa kondisi sosial kemasyarakatan pasca reformasi memperlihatkan adanya degradasi nilai masyarakat yang jauh dari tatanan dan nilai moral bangsa Indonesia. Pendidikan karakter berkaitan dengan keseluruhan kemampuan seseorang dalam berinteraksi dengan lingkungannya, sebab hal itu berkaitan dengan unsur moral, sikap sampai dengan perilaku. Sebuah karakter dikatakan baik apabila eseorang memiliki kemampuan atas pengetahuan sebuah moral, perasaan moral dan tindakan moral.

Oleh karena secara substantif pendidikan karakter berkenaan dengan pendidikan afektif yaitu berkenaan dengan dunia kejiwaan, cita-cita dan rasa, citra serta keyakinan manusia, maka keyakinan seseorang akan sesuatu yang paling 
baik merupakan hasil belajar. Sebagai hasil dari proses internalisasi secara nalar dari peserta didik terhadap nilainilai kebenaran dan kebaikan. IPS merupakan rumpun yang diharapkan secara efektif dapat memberikan muatan besar pendidikan karakter sebab IPS mampu memfasilitasi peserta didik untuk membangun pengetahuan, beradaptasi dengan lingkungan, membudayakan dirinya dengan lingkungan yang kesemuanya dapat dikembangkan melalui pembelajaran yang power full sosial studies atau dengan melalui pendekatan berbagai disiplin ilmu-ilmu sosial. 


\section{DAFTAR RUJUKAN}

Daljoeni. 1992. Dasar-dasar IPS. Bandung: Alumni.

Jarolimek, J. 1982. Sosial Studies in Elementary Education. London: McMillan.

Masruki. 2011. Model-model Pembelajaran Pendidikan Karakter. Makalah dalam Seminar.

Miarso, Y. H. 2003. Pembelajaran Kontekstual dan Penerapannya. Jakarta: Gramedia.

Nasution.1982. Berbagai Pendekatan dalam Proses Belajar dan Mengajar. Bandung. Bumi Aksara.

Nurcahyo, A. 2010. Konsep dasar IPS. Magetan: Swastika.

Suhartono. 2001. Model-model Pembelajaran Pendidikan Karakter. Makalah dalam Seminar.

Sardiman, A.M. 2001. Interaksi dan Motivasi Belajar Mengajar, Jakarta, PT Raja Grafindo Persada.

Undip. Nasional Aktualisasi Arsip dan Fungsi Arsip Sebagai Simpul Integrasi Bangsa dalam Pembangunan Karakter Bangsa. Semarang: ANRI Undip.

Wahab, A. A. 2007. Metode dan Model Mengajar IPS. Jakarta: Alfabeta.

Winataputra, U. 2001. Strategi Belajar Mengajar. Jakarta: Universitas Terbuka. 